удК

$$
\begin{aligned}
& \text { 37.014.5-057.874-054.7(=163.3/.6)(4-191.2)"197" } \\
& \text { 314.151.3-057.874(=163.3/.6)(4-191.2)"197" } \\
& \text { 371.3:81'242(=163.3/.6)(4-191.2)"197" }
\end{aligned}
$$

Оригиналан научни рад

Примљен: 19. 7. 2016.

Прихваћен: 16. 1.2017.

Petar DRAGIŠIĆ

Institut for Recent History of Serbia petar.dragisic@gmail.com

\title{
Mother Tongue Tuition for Yugoslav Children in German-Speaking Countries in the 1970s*
}

\begin{abstract}
The paper deals with the mother tongue tuition for children of Yugoslav immigrants in the German-speaking countries in the 1970s, focusing primarily on the organization of the Yugoslav educational program abroad, the curricula, the role of the host countries as well as the ideological aspects of the Yugoslav courses in the Federal Republic of Germany, Austria and Switzerland. In addition, the research includes an analysis of political background of this sensitive issue. The research was carried out in the Archive of Yugoslavia.
\end{abstract}

Key words: immigrants, children, Yugoslavia, mother tongue tuition, ideology

The economic stagnation in Yugoslavia, accompanied by population boom enormously increased the pressure on the Yugoslav labour market in the 1960s. The economic reforms in Yugoslavia, launched in 1961 and 1965 respectively, did not boost the Yugoslav economy. Moreover, in the following years a number of economic indicators (GDP growth, industrial production index, balance of payments deficit, investment fall,

This article has been written within the framework of the scholarly project Tradition and Transformation - Historical Heritage and National Identity in Serbia in $20^{\text {th }}$ Century (№ 47019), financed by the Ministry of Education, Science and Technological Development Republic of Serbia. 
and price increase) continued to show a stagnant economy of socialist Yugoslavia. In 1966 the inflation rate rose to almost 30\%. ${ }^{1}$

The economic slowdown in Yugoslavia in the 1960s coincided with the considerable population growth. Between 1953 and 1961, the Yugoslav population increased by approximately 1.5 million $(16,936,573$ in 1953/18,549,291 in 1961). ${ }^{2}$ This specific combination of economic and demographic trends badly hit the Yugoslav job market in the 1960s and 1970s. Consequently, from 1964 to 1968 the number of Yugoslav job seekers increased by 47 percent. The rising unemployment, accompanied by considerably lower salaries in comparison to the West European countries, led to the mass emigration from Yugoslavia in the 1960s. In the following decades this phenomenon had profound political, economic and cultural consequences for the Yugoslav society. The Yugoslav regime actively participated in this undertaking, particularly through bilateral agreements with the key host countries. ${ }^{3}$

In the following years the labour migration from Yugoslavia greatly intensified reaching a peak in 1973, when, according to Yugoslav sources, the number of Yugoslavs "temporarily employed abroad" exceeded one million. After the zenith in 1973, the number of Yugoslav "workers temporarily employed abroad" slightly decreased amounting in 1977 roughly 800,000. The vast majority of Yugoslav job seekers (three quarters of the total number of Yugoslav Gastarbeiter in 1973) settled in the German-speaking countries. ${ }^{4}$ Outside the German-speaking area,

1 Branko Petranović, Istorija Jugoslavije 1918-1988, (Beograd: Nolit, 1989), III/380382; Dušan Bilandžić, Historija Socijalističke Federativne Republike Jugoslavije. Glavni procesi, (Zagreb: Školska knjiga, 1978), 247-319; Marie-Janine Calic, Geschichte Jugoslawiens im 20. Jahrhundert, (München: C. H. Beck, 2010), 227-229.

2 Branko Petranović, Momčilo Zečević, Jugoslavija 1918-1988. Tematska zbirka dokumenata, (Beograd: Rad, 1988), 1198.

3 Bilandžić, Historija, 318; Calic, Geschichte Jugoslawiens, 229.

4 Arhiv Jugoslavije (Archives of Yugoslavia - AJ), Socijalistički savez radnog naroda Jugoslavije (142), f-740(a), Savezni komitet za rad i zapošljavanje, Izveštaj o ostvarenju politike zapošljavanja u inostranstvu i postepenog vraćanja jugoslovenskih građana sa privremenog boravka u inostranstvu u 1977. godini, mart 1978. godine. On labour emigration from Yugoslavia see: Ulf Brunnbauer, „Labour Emigration from the Yugoslav Area from the late 19th Century until the End of Socialism: Continuities and Changes", Transnational Societies, Transterritorial Politics. Migrations in the (Post-Yugoslav Region, 19th-21 $1^{\text {st }}$ Century, Ulf Brunnbauer (Hg.), (München: R. Oldenbourg Verlag, 2009), (=Südosteuropäische Arbeiten, 141), 17-50; Ulf Brunnbauer, "Jugoslawische Geschichte als Migrationsgeschichte (19. und 20. Jahrhundert)“, Schnittstellen. Gesellschaft, Nation, Konflikt und Erinnerung in Südosteuropa. Festschrift für Holm Sundhaussen zum 65. Geburtstag, Ulf Brunnbauer, Andreas Helme- 
the biggest Yugo communities in Western Europe were located in France (75,000 in 1973) and Sweden (25,000 in 1973)..$^{5}$ Children comprised a considerable portion of the Yugoslav migrant population. According to Yugoslav sources, in 1977 in Federal Republic of Germany there were 120.000 Yugoslav children under the age of $15 .^{6}$

The mass emigration from socialist Yugoslavia considerably contributed to stabilization of the Yugoslav communist regime. The emigration of hundreds of thousands of Yugoslavs eased the pressure on the Yugoslav labour market. Besides, the remittances of Yugoslav labour migrants constituted an important source of foreign currency for the Yugoslav regime. Therefore, the Yugoslav establishment perceived the emigration from Yugoslavia as a lucrative business, in which the Yugoslav

dach, Stefan Troebst (Hg.), (München: R. Oldenbourg, 2007), 111-132; Ulf Brunnbauer, „Emigration aus Südosteuropa, 19.-21. Jahrhundert. Kontinuitäten, Brüche, Perspektiven“, Südosteuropa. Traditionen als Macht, Emil Brix, Arnold Suppan, Elisabeth Vyslonzil (Hg.), (Wien/München: Verlag für Geschichte und Politik/Oldenbourg Wissenschaftsverlag, 2007), (= Schriftenreihe des österreichischen Ost- und Südosteuropa-Instituts, Bd. 31), 119-142; Ivana Dobrivojević, „U potrazi za blagostanjem. Odlazak jugoslovenskih radnika na rad u zemlje Zapadne Evrope 1960-1976“, Istorija 20. veka 1/2008, 89-100; Slobodan Selinić, „Ekonomska emigracija iz Jugoslavije šezdesetih godina XX veka", 1968 - četrdeset godina posle, urednik Radmila Radić, (Beograd, 2008), 549-573; Otmar Nikola Haberl, Die Abwanderung von Arbeitskräften aus Jugoslawien, (München, 1978); Wilfried Künne, Die Auswanderung jugoslawischer Arbeitskräfte. Ein Beitrag zur Analyse internationaler Arbeitskräftewanderung, (Harnstein, 1979); Ivo Baučić, Social Aspects of External Migration of Workers and the Yugoslav Experience in the Protection of Migrants, (Zagreb: Centar za istraživanje migracija Instituta za geografiju Sveučilišta, 1975); Österreich-Jugoslawien: Determinanten und Perspektiven ihrer Beziehungen, Otmar Höll (Hg.), (Wien, 1988); Vladimir Ivanović, Geburtstag pišeš normalno: jugoslovenski gastarbajteri u SR Nemačkoj i Austriji: 1965-1973, (Beograd, 2012); Predrag J. Marković, „Verloren in der Transmigration? Der Einfluss der serbischen Gastarbeiter auf das Alltagsleben in Serbien", Arbeitswelt-Lebenswelt, Klaus Roth (Hg.), (Münster, 2004), 239-256; Petar Dragišić, „Jugoslovenski ekonomski migranti u Austriji od početka 60-ih godina do raspada Jugoslavije“, Tokovi istorije 1-2/2009, 55-65; Petar Dragišić, „Klubovi jugoslovenskih radnika u Zapadnoj Evropi 70-ih godina“, Tokovi istorije 1/2010, 128-138; Petar Dragišić, „Ein Volk unterwegs. Migranten aus Serbien 1971-2002“, Themenportal Europäische Geschichte, datum pristupa 15. 10. 2016, http://www.europa.clio-online. $\mathrm{de} / 2010 /$ Article $=447$.

5 AJ, 142, f-740(a), Savezni komitet za rad i zapošljavanje, Izveštaj o ostvarivanju politike zapošljavanja, zapošljavanja u inostranstvu i postepenog vraćanja jugoslovenskih građana sa privremenog rada u inostranstvu u 1977. godini, mart 1978. godine.

6 AJ, 142, f-277 (a), Savezni sekretarijat za inostrane poslove (Uprava za radnike u inostranstvu), Jugoslovenski građani na privremenom radu u SR Nemačkoj, Problematika zapošljavanja, rada i boravka, jun 1978. 
regime actively participated. Nevertheless, this experiment involved certain elements of political and economic risks. The Yugoslav regime was afraid of a potentially negative impact of emigration of skilled workers on the Yugoslav economy. In addition, the emigration from Yugoslavia in the 1960s and 1970s posed a serious ideological and political threat to the socialist system in Yugoslavia. The Yugoslav regime was particularly anxious about potential deviation of Yugoslav labour migrants in Western Europe from the Yugoslav ideological postulates. In this regard, the regime was deeply worried about the influence of Yugoslav political emigration on the Yugoslav Gastarbeiter communities. Therefore, the Yugoslav regime endeavoured to control Yugoslav labour migrants and their family members trying to prevent their ideological and political "brainwashing" abroad. For this purpose, the Yugoslav regime created a network of migrants' clubs and associations. ${ }^{7}$ In addition, the Yugoslav communist establishment used the mother tongue instruction for $\mathrm{Yu}-$ goslav children abroad to subject the offspring of the Yugoslav migrant workers to subtle political and ideological indoctrination and strengthen their ties with Yugoslavia.

The mother tongue tuition for Yugoslav children in the Federal Republic of Germany and Switzerland was launched in 1970 and 1971 respectively. The introduction of the Yugoslav courses in Austria was discussed during the visit of Austrian minister of education, Fred Sinowatz, to Yugoslavia in March 1973 and the subsequent Yugoslav-Austrian negotiations on bilateral cultural cooperation. However, the negotiations were hampered by the lack of consensus among the Austrian states (Bundesländer) over this issue. The opposition was particularly strong in Upper Austria (Oberösterreich) and Vorarlberg. Besides, the authorities of the Austrian capital, Vienna, argued against this form of education claiming that the additional tuition would heavily encumber Yugoslav children in Austria. Nevertheless, in 1975 Austria agreed to allow the introduction of the mother tongue tuition for the children of Yugoslav immigrants. ${ }^{8}$

Soon after it officially started, the Yugoslav tuition in Western Europe became fully operational. In the mid-1970s, fifty percent of Yugoslav schoolchildren in the German speaking countries attended the Yugoslav courses. According to Yugoslav sources, in the Federal Republic of Germany, about 14,000 Yugoslav children were enrolled in the extra

7 Dragišić, „,Klubovi jugoslovenskih radnika“, 128-138.

8 Werner Weilguni, Österreichisch-jugoslawische Kulturbeziehungen: 1945-1989, (München, 1990), 59. 
tuition in Yugoslav languages. In the mid-1970s the number of Yugoslav participants in the courses in Yugoslav languages in Austria and Switzerland was considerably lower - circa 3,000.

Migrant children participating in the Yugoslav educational program School Year 1975/1976 ${ }^{9}$

\begin{tabular}{|l|r|r|}
\hline & \multicolumn{1}{|c|}{$\begin{array}{c}\text { Number of pupils } \\
\text { participating } \\
\text { in Yugoslav tuition }\end{array}$} & \multicolumn{2}{c|}{$\begin{array}{c}\text { Total number } \\
\text { of Yugoslav } \\
\text { schoolchildren }\end{array}$} \\
\hline West Germany & 14,000 & 27,000 \\
\hline Sweden & 2,000 & 5,400 \\
\hline Austria & 1,850 & 5,200 \\
\hline France & 1,500 & 6,500 \\
\hline Switzerland & 1,200 & 2,500 \\
\hline Great Britain & 500 & 1,000 \\
\hline Netherlands & 310 & 350 \\
\hline Denmark & 300 & 500 \\
\hline Belgium & 140 & 1,000 \\
\hline Luxembourg & 40 & 100 \\
\hline Norway & 30 & 50 \\
\hline Total & 21,870 & 49,600 \\
\hline
\end{tabular}

A year later, the number of participants in the Yugoslav educational program in the Federal Republic of Germany rose to more than 16,500 . The program was particularly successful in the German western states - Baden-Württemberg and Nordrhein-Westfalen. ${ }^{10}$

\section{$9 \quad$ Ibid.}

10 AJ, 142, f-277(a), Savezni sekretarijat za inostrane poslove (Uprava za radnike u inostranstvu), Jugoslovenski građani na privremenom radu u Saveznoj Republici Nemačkoj - Problematika zapošljavanja, rada i boravka, jun 1978. 
Number of migrant children participating in the Yugoslav educational program in the Federal Republic of Germany in $1977^{11}$

\begin{tabular}{|l|r|}
\hline \multicolumn{1}{|c|}{ State } & $\begin{array}{c}\text { Schoolchildren participating } \\
\text { in the Yugoslav educational } \\
\text { programme }\end{array}$ \\
\hline Baden-Württemberg & 6,740 \\
\hline Nordrhein-Westfalen & 3,981 \\
\hline Hessen, Saarland, Rheinland-Pfalz & 2,954 \\
\hline Bavaria & 1,226 \\
\hline Berlin & 850 \\
\hline Hamburg, Bremen, Schleswig-Holstein & 680 \\
\hline Niedersachsen & 546 \\
\hline Total & 16,617 \\
\hline
\end{tabular}

In Austria, the level of participation in the Yugoslav mother tongue tuition was particularly high in Vienna, which corresponded to the size of the Yugoslav community in the Austrian capital. According to Yugoslav sources, in the late 1970s Burgenland was the only Austrian state in which the idea of Yugoslav mother tongue education for children of Yugoslav migrants was not put in practice. $^{12}$

11 Ibid.

12 AJ, 142, f-276(a), Ambasada SFRJ u Austriji, Godišnji izveštaj o dopunskoj nastavi na maternjem jeziku za decu naših građana privremeno zaposlenih u Austriji za $1977 / 78$. godinu. 
Yugoslav pupils in Austria participating in the mother tongue tuition School Year 1977/1978 13

\begin{tabular}{|l|r|}
\hline \multicolumn{1}{|c|}{ State } & \multicolumn{2}{c|}{$\begin{array}{c}\text { Schoolchildren from Yugoslavia } \\
\text { participating in the mother tongue } \\
\text { educational program }\end{array}$} \\
\hline Vienna & 1,790 \\
\hline Vorarlberg & 587 \\
\hline Lower Austria & 328 \\
\hline Salzburg & 215 \\
\hline Upper Austria & 117 \\
\hline Tyrol & 94 \\
\hline Carinthia & 56 \\
\hline Styria & 27 \\
\hline Total & 3,214 \\
\hline
\end{tabular}

The mother tongue tuition for Yugoslav schoolchildren abroad was not carried out exclusively in Serbo-Croatian language. In the second half of the 1970s, the Yugoslav educational program in the Federal Republic of Germany, Austria and Switzerland included also courses in Slovenian and Macedonian language. Besides, the mother tongue tuition in the Federal Republic of Germany also included the children of Yugoslav migrants of Albanian, Hungarian and Slovak origin. ${ }^{14}$

The vast majority of Yugoslav schoolchildren in the German speaking countries attended the Yugoslav tuition in Serbo-Croatian language. In the second half of the 1970s, 95 percent of participants in the Yugoslav tuition in Austria were taught in Serbo-Croatian languages. ${ }^{15}$ The situation was similar in the Federal Republic of Germany and

13 Ibid.

14 AJ, 142, f-275(a), Savezni zavod za međunarodnu naučnu, prosvetno-kulturnu i tehničku saradnju, Savetovanje o dopunskoj nastavi (Novi Sad 29-30. 6. 1976); AJ, 142, f-276(a), Ambasada SFRJ Beč, Godišnji izveštaj o dopunskoj nastavi na maternjem jeziku za decu naših građana privremeno zaposlenih u Austriji za 1977/78. godinu.

15 AJ, 142, f-276(a), Ambasada SFRJ Beč, Godišnji izveštaj o dopunskoj nastavi na maternjem jeziku za decu naših građana privremeno zaposlenih u Austriji za 1977/1978. godinu. 
Switzerland.${ }^{16}$ According to the reports of the Yugoslav embassy in Bern, in 1977 approximately 90 percent of the Yugoslav children, attending the Yugoslav courses in the host country, came from Serbo-Croatian-speaking Yugoslav federal units - Serbia, Croatia, Bosnia and Hercegovina, and Montenegro. ${ }^{17}$

The models of funding of the mother-tongue education for Yugoslav schoolchildren in Western Europe in the 1970s differed from country to country. In Switzerland, the program was entirely funded by Yugoslavia, while in Austria the Yugoslav education was financed both by Yugoslavia and the host country. Austria provided salaries for Yugoslav teaching staff as well as teaching materials for the Yugoslav mother-tongue education. Nevertheless, Yugoslavia financially supported Yugoslav teachers in the Austria by awarding them bonus payments (5,500 Schillings a month in 1977). Besides, Yugoslavia provided Yugoslav teaching staff and Yugoslav schoolchildren with additional teaching materials, such as textbooks, maps as well as Yugoslav journals. ${ }^{18}$

In the Federal Republic of Germany the states were free to negotiate with Yugoslav federal authorities on models of funding the Yugoslav tuition. As a result, in West Germany of the 1970s there were three forms of funding the Yugoslav courses. In Hessen, Nordrhein-Westfalen and Bavaria the mother-tongue education for Yugoslav pupils were fully funded by German partners. Quite the contrary, in Rheinland-Pfalz, Saarland, Hamburg and Bremen the project was entirely financed by Yugoslavia. An exception was Baden-Württemberg, where the Yugoslav tuition was jointly funded by Yugoslavia and the local government. ${ }^{19}$

16 AJ, 142, f-276(a), Generalni konzulat SFRJ Štutgart, Godišnji izveštaj o dopunskoj nastavi na maternjem jeziku za decu naših građana privremeno zaposlenih u Štutgartu za 1977. godinu; AJ, 142, f-276(a), Generalni konzulat SFRJ Hamburg, Godišnji izveštaj o školovanju jugoslovenske dece za 1977. godinu; AJ, 142, f-276(a), Vojna misija - Zapadni Berlin, Godišnji izveštaj o dopunskoj nastavi na maternjem jeziku za decu naših građana privremeno zaposlenih u Zapadnom Berlinu za 1977. godinu.

17 AJ, 142, f-276(a), Ambasada SFRJ Bern, Godišnji izveštaj o dopunskoj nastavi na maternjem jeziku za decu naših građana privremeno zaposlenih u Švajcarskoj za 1977. godinu.

18 AJ, 142, f-277(a), Savezni sekretarijat za inostrane poslove (Uprava za radnike u inostranstvu), Jugoslovenski građani na privremenom radu u Švajcarskoj - Problematika zapošljavanja, rada i boravka, jun 1978; AJ, 142, f-276(a), Ambasada SFRJ Beč, Godišnji izveštaj o dopunskoj nastavi na maternjem jeziku za decu naših građana privremeno zaposlenih u Austriji za 1977. godinu.

19 AJ, 142, f-275(a), Savezni zavod za međunarodnu naučnu, prosvetno-kulturnu i tehničku saradnju, Informacija o trenutnoj situaciji u oblasti školovanja dece jugoslovenskih građana na privremenom radu u Saveznoj Republici Nemačkoj. 
The teaching staff in charge of the mother-tongue education for Yugoslav schoolchildren abroad was recruited in two ways. They were either sent from Yugoslavia, or selected from the Yugoslav migrants. The number of teachers in the German-speaking countries corresponded to the size of the local Yugoslav communities. In 1975/1976 almost 200 teachers were responsible for the education of Yugoslav migrant children in the Federal Republic of Germany in their mother-tongues. The number of Yugoslav teachers in Austria and Switzerland was considerably lower -56 and 24 respectively. ${ }^{20}$

Teaching staff in charge of the Yugoslav tuition in Western Europe in 1975/1976 ${ }^{21}$

\begin{tabular}{|l|r|}
\hline West Germany & 196 \\
\hline Sweden & 175 \\
\hline Switzerland & 56 \\
\hline France & 28 \\
\hline Austria & 24 \\
\hline Netherlands & 20 \\
\hline Great Britain & 11 \\
\hline Denmark & 6 \\
\hline Belgium & 3 \\
\hline Norway & 2 \\
\hline Luxembourg & 1 \\
\hline Total & 522 \\
\hline
\end{tabular}

The mother tongue tuition for Yugoslav schoolchildren abroad represented an important segment of Yugoslav emigration strategy. According to available sources, the Yugoslav education for migrant children was clearly prompted by political motives. Through this program the Yu-

20 AJ, 142, f-275(a), Savezni zavod za međunarodnu naučnu, prosvetno-kulturnu i tehničku saradnju, Savetovanje o dopunskoj nastavi (Novi Sad, 29-30. 6. 1976).

21 Ibid. 
goslav regime endeavoured to prevent westernization of Yugoslav pupils abroad and tie them closely to their homeland. Besides, given that the Yugoslav regime anticipated the return of considerable portion of Gastarbeiter, the ideological indoctrination of Yugoslav children abroad should have facilitated their reintegration into the Yugoslav socialist system. Consequently, the mother-tongue education for Yugoslav schoolchildren was perceived as an important political issue. ${ }^{22}$

In a document composed in 1970, the Yugoslav Bureau for Education and Culture outlined key objectives of the mother-tongue tuition for children of Yugoslav migrants. The authors of the document underlined the importance of the Yugoslav tuition abroad for linking the offspring of Yugoslav migrants to their homeland. According to this document, the program aimed to provide Yugoslav schoolchildren with basic facts on Yugoslav policy and economy and infuse the Marxist Weltanschauung into the Yugoslav youth abroad. The final result should have been a young person, loyal to his/her homeland and ready to fight for its independence. ${ }^{23}$

Like Italian tuition abroad, ${ }^{24}$ the mother-tongue educational programs for children of Yugoslav migrants consisted of the "national" subjects. In Switzerland the Yugoslav education covered mother tongue classes, geography (for older pupils), history (for older pupils) and the subject "My homeland" (Moja domovina) for younger Yugoslav schoolchildren in Switzerland. ${ }^{25}$

The subject "My homeland" comprised facts on "natural beauties" and cultural heritage of Yugoslavia as well as on the history of the Yugoslav peoples. The didactic goal of this subject was to strengthen the ties between the migrant children from Yugoslavia and their motherland. ${ }^{26}$ The courses in history focused on topics related to the Second

22 AJ, 142, f-275(a), Odsek za školovanje jugoslovenske dece u inostranstvu, Informacija o nekim aktuelnim organizacionim pitanjima dopunske nastave za decu jugoslovenskih građana, 8. 6. 1976; AJ, 142, f-275(a), Savazni zavod za međunarodnu naučnu, prosvetno-kulturnu i tehničku saradnju, Savetovanje o dopunskoj nastavi (Novi Sad, 30. 6. 1976.)

23 AJ, 142, f-474, Savezni zavod za obrazovanje i kulturu, Društveno-pedagoška osnova obrazovno-vaspitnog rada sa decom naših radnika privremeno zaposlenih u inostranstvu i predlozi za rešavanje problema njihovog školovanja, 5. 5. 1970.

24 Ibid.

25 AJ, 142, f-275(a), Informacija ambasade SFRJ u Bernu o jugoslovenskim dopunskim školama na području Švajcarske, april 1976.

26 Ibid. 
World War and the subsequent socialist revolution in Yugoslavia emphasizing traditional connections between the Yugoslav peoples. ${ }^{27}$ According to the report of the Yugoslav embassy in Bern, the courses in geography had also an obvious ideological function. The purpose of the geography lessons was to introduce Yugoslav pupils to the basic characteristics of the Yugoslav system and promote "Yugoslav socialist patriotism." 28

The promotion of Tito's cult of personality was one of the key elements of the Yugoslav educational system abroad. The available Yugoslav sources contain several striking examples of this form of political and ideological indoctrination of Gastarbeiters' offspring. In 1978, the Yugoslav migrant children in Switzerland, participating in the Yugoslav educational program, were invited to compose essays on the Yugoslav leader under the title "Tito - A Symbol of our Youth" (Tito - simbol naše mladosti). A year earlier, an identical action was carried out in the West German state Hessen. ${ }^{29}$

Given the Cold War polarization and the consequent climate of mistrust towards any form of Marxist propaganda in the West, the ideological components of the mother tongue tuition for Yugoslav schoolchildren abroad was met with negative reactions in host countries. In some comments, the Yugoslav educational program was described as a "Marxist subversion." In the Federal Republic of Germany the campaign against the Yugoslav tuition was particularly vigorous in 1977, when the local press severely criticized the curricula of the Yugoslav courses, the activities of Yugoslav teachers and the contents of textbooks used in the Yugoslav tuition. ${ }^{30}$ In addition, the Yugoslav sources indicate a widespread mistrust of the Yugoslav courses in Austria, which resulted in banning several Yugoslav textbooks. ${ }^{31}$

Despite the minor criticism of the mother tongue tuition for Yugoslav migrant children, in the 1970s the host countries did not obstruct the Yugoslav educational program. Quite the contrary, several West German states participated in funding the mother tongue education for Yugoslav schoolchildren. Consequently, in the late 1970s the program

\footnotetext{
27 Ibid.

28 Ibid.

29 AJ, 142, f-276(a), Generalni konzulat SFRJ Frankfurt, Dopunsko školovanje (1976).

30 AJ, 142, f-276(a), Savezni zavod za međunarodnu naučnu, prosvetno-kulturnu i tehničku saradnju, Izveštaj o radu u 1977. godini.

31 Ibid.
} 
gained ground, including considerable number of Yugoslav pupils in the German-speaking countries.

The available sources on the Yugoslav tuition in the German-speaking countries do not allow an objective evaluation of its effects. Undoubtedly, the program must have contributed to confused Weltanschauung of Yugoslav migrant children. While being surrounded by capitalist ethic and the culture of consumerism, the children of Yugoslavs "temporarily employed abroad" were taught about advantages of the Yugoslav road to socialism. As a result, the Yugoslav children attending the mother tongue courses were already at an early stage of their lives faced with difficult ideological and ethical dilemmas.

\section{Sources and Literature}

\section{Sources}

- Archives of Yugoslavia (Arhiv Jugoslavije - AJ). Fond: Socijalistički savez radnog naroda Jugoslavije (142).

\section{Literature}

- Baučić, Ivo. Social Aspects of External Migration of Workers and the Yugoslav Experience in the Protection of Migrants. Zagreb: Centar za istraživanje migracija Instituta za geografiju Sveučilišta, 1975.

- Bilandžić, Dušan. Historija Socijalističke Federativne Republike Jugoslavije. Glavni procesi. Zagreb: Školska knjiga, 1978.

- Brunnbauer, Ulf. „Labour Emigration from the Yugoslav Area from the late 19th Century until the End of Socialism: Continuities and Changes". Transnational Societies, Transterritorial Politics. Migrations in the (Post-)Yugoslav Region, 19th-21 $1^{\text {st }}$ Century, Ulf Brunnbauer (Hg.). München: R. Oldenbourg Verlag, 2009 (= Südosteuropäische Arbeiten, 141), 17-50.

- Brunnbauer, Ulf. „Jugoslawische Geschichte als Migrationsgeschichte (19. und 20. Jahrhundert)“. Schnittstellen. Gesellschaft, Nation, Konflikt und Erinnerung in Südosteuropa. Festschrift für Holm Sundhaussen zum 65. Geburtstag, Ulf Brunnbauer, Andreas Helmedach, Stefan Troebst (Hg.). München: R. Oldenbourg, 2007, 111-132.

- Brunnbauer, Ulf. „Emigration aus Südosteuropa, 19.-21. Jahrhundert. Kontinuitäten, Brüche, Perspektiven“. Südosteuropa. Traditionen als Macht, Emil Brix, Arnold Suppan, Elisabeth Vyslonzil (Hg.). Verlag für 
Geschichte und Politik/Oldenbourg Wissenschaftsverlag, (= Schriftenreihe des österreichischen Ost- und Südosteuropa-Instituts, Bd. 31), Wien/München, 2007, 119-142.

- Calic, Marie-Janine. Geschichte Jugoslawiens im 20. Jahrhundert. München: C. H. Beck, 2010.

- Dobrivojević, Ivana. „U potrazi za blagostanjem. Odlazak jugoslovenskih radnika na rad u zemlje Zapadne Evrope 1960-1976“. Istorija 20. veka $1 / 2008,89-100$.

- Dragišić, Petar. „Jugoslovenski ekonomski migranti u Austriji od početka 60-ih godina do raspada Jugoslavije“. Tokovi istorije 1-2/2009, 55-65.

- Dragišić, Petar. „Klubovi jugoslovenskih radnika u Zapadnoj Evropi 70-ih godina“. Tokovi istorije 1/2010, 128-138.

- Haberl, Otmar Nikola. Die Abwanderung von Arbeitskräften aus Jugoslawien. München, 1978.

- Ivanović, Vladimir. Geburtstag pišeš normalno: jugoslovenski gastarbajteri u SR Nemačkoj i Austriji: 1965-1973. Beograd: Institut za savremenu istoriju, 2012.

- Marković, Predrag J. „Verloren in der Transmigration? Der Einfluss der serbischen Gastarbeiter auf das Alltagsleben in Serbien“. ArbeitsweltLebenswelt, Klaus Roth (Hg.). Münster, 2004, 239-256.

- Österreich-Jugoslawien: Determinanten und Perspektiven ihrer Beziehungen, Otmar Höll (Hg.). Wien, 1988.

- Petranović, Branko. Istorija Jugoslavije 1918-1988. Beograd: Nolit, 1989.

- Petranović, Branko i Momčilo Zečević. Jugoslavija 1918-1988. Tematska zbirka dokumenata. Beograd: Rad, 1988.

- Selinić, Slobodan. „Ekonomska emigracija iz Jugoslavije šezdesetih godina XX veka“. 1968 - četrdeset godina posle, urednik Radmila Radić, 549-573. Beograd: INIS, 2008.

- Weilguni, Werner. Österreichisch-jugoslawische Kulturbeziehungen: 1945-1989. München, 1990. 


\title{
Резиме
}

Петар Драгишић

\section{Настава на матерњем језику за југословенску децу у земљама немачког говорног подручја седамдесетих година 20. века}

\begin{abstract}
Апстракт: Овај рад се бави наставом на матерњем језику организованом за децу југословенских миграната у земљама немачког говорног подручја седамдесетих година двадесетог века и фокусира се пре свега на југословенски образовни програм у иностранству, распоред, улогу земаља-домаћина, као и на идеолошке аспекте југословенске наставе у Савезној Републици Немачкој, Аустрији и Швајцарској. Поред тога, анализирана је и политичка позадина овог осетљивог питања. Истраживање је спроведено у Архиву Југославије.
\end{abstract}

Кључне речи: мигранти, деца, Југославија, настава на матерњем језику, идеологија

Велики талас емигрирања из Југославије шездесетих и почетком седамдесетих година довео је до стварања заједница југословенских гастарбајтера у Западној Европи, од којих су се најбројније налазиле у земљама немачког говорног простора. Тадашњи југословенски режим је настојао да на различите начине контролише економску емиграцију и спречи њено дистанцирање од матице. Тој сврси требало је, поред осталог, да послужи и разграната мрежа клубова југословенских миграната у иностранству.

На најмлађе југословенске мигранте - децу југословенских гастарбајтера у иностранству - режим у Југославији настојао је да утиче пре свега путем организовања допунске наставе на матерњем језику. Будући да је убедљиво највећи број југословенских економских миграната живео и радио у земљама немачког говорног простора, у тим државама је и југословенска допунска настава била најмасовнија. Средином седамдесетих година је готово 2/3 укупног броја 
деце обухваћене југословенском допунском наставом у Западној Европи школу похађало у Савезној Републици Немачкој.

Југословенски режим је спровођење допунске наставе за децу југословенских миграната у значајној мери координирао са земљама-домаћинима, али и поред тога доступни извори указују и на извесно незадовољство земаља-домаћина неким сегментима програма југословенске допунске наставе. Ова настава је децу југословенских гастарбејтера свакако суочавала са одређеним вредносним и идеолошким дилемама, јер су поруке које су им преношене често значајно одступале од капиталистичког контекста у којем су живела. 